\title{
Effects of Metformin and Metformin Plus Glibenclamide on Glucose-6- Phosphatase Status and Some Biochemical Parameters in Type 2 Diabetic Patients
}

\author{
Zainab S. Hallab*, Alaa H. Jawad* and Perry H. Saifullah ${ }^{* *}$ \\ * Department of Chemistry, College of Sciences, Al-Nahrain University, Baghdad-Iraq. \\ ** Department of Chemistry, College of Sciences for Women, University of Baghdad, \\ Baghdad-Iraq.
}

\begin{abstract}
This research was done to assess the effects of anti diabetic drugs (metformin and metformin plus glibenclamide) on Glucose-6-phosphatase activity, serum leptin concentration, Fasting plasma glucose (FPG), Glycated hemoglobin (HbA1c\%) and lipid profile in type 2 diabetic patients. The study involved 64 patients suffering from type 2 diabetes mellitus. They were divided into 3 groups. The first group involves 23 newly diagnosed diabetic patients, who did not take any hypoglycemic agents. The second group involves 21 patients on metformin monotherapy, whereas the third group involves 20 patients on metformin plus glibenclamide combination therapy. Another group which involved 20 apparently healthy subjects was used as control group. Age, Body mass index (BMI), FPG, HbA1c \%, lipid profile, Glucose-6-phosphatase activity and serum leptin concentration have been determined. The results showed that the activity of Glucose-6-phosphatase was lower in metformin and metformin plus glibenclamide groups when compared with newly diagnosed group and closer to that of control group, leptin concentration was lower in metformin group than that in metformin plus glibenclamide group and these two groups were lower than newly diagnosed group, the levels of FPG, $\mathrm{HbA} 1 \mathrm{C} \%$ were reduced in metformin and metformin plus glibenclamide groups when compared with newly diagnosed group and metformin alone produce a non-significant favorable effect on all lipids profile parameters, while metformin plus glibenclamide showed a significant reduction in Total Cholesterol (TC) and Low Density Lipoprotein LDL-C. In conclusion, using metformin as a mono therapy or combination with glibenclamide can reduce Glucose-6phosphatase activity, FPG and $\mathrm{HbA1c} \%$ levels in type 2 diabetic patients and metformin monotherapy reduced leptin levels more than metformin combination with glibenclamide in type 2 diabetic patients patients so Glucose-6-phosphatase activity and serum leptin concentration can be used as an indicator for the choice of treatment in those diabetic patients.
\end{abstract}

Keywords: Type 2 DM, Glucose-6-phosphatase, leptin, Glibenclamide, Metformin, HbA1c \%.

\section{Introduction}

Diabetes mellitus (DM) is a group of metabolic diseases characterized by hyperglycemia resulting from defects in insulin secretion, insulin action, or both. The chronic hyperglycemia of diabetes is associated with long-term damage, dysfunction and failure of various organs T2DM is the most common type of diabetes, accounting for $90-95 \%$ of all diabetes [1]. It usually develops after the age of 40 . However, in the late 1990's, its incidence increased among young people. Experts is trying to determine why that is happening; they think it may be related to the increased incidence of obesity and sedentary lifestyles among young people in the USA. About $80 \%$ of those with type 2 diabetes are overweight [2].

The liver plays an important role in the regulation of blood glucose levels. At time of strees or whenever blood glucose fall, the liver rapidly releases glucose in to the blood stream, which carries it to other tissues (e.g.,brain and muscle) that cannot make glucose[3]. The two pathways by which the liver can make glucose are gluconeogenesis and glycogenolysis. one enzyme, Glucose-6-phosphatase (G6Pase), catalyzes the terminal step of both pathways by converting glucose-6-phosphate (G-6-P) to glucose and inorganic phosphate[4].

Glucose-6-phosphatase found mainly in the liver and the kidney cortex, plays the important role of providing glucose during 
starvation [5]. In type 2 diabetes the resistance of liver to insulin leads to uncontrolled gluconeogenesis there is an overexpression of glucose-6-phosphatase, leading to increased endogenous glucose production [6].

Leptin is a hormone secreted by adipocytes that regulates energy metabolism via peripheral action on glucose synthesis and utilization as well as through central regulation of food intake [7]. Obesity, a state of hyperleptinemia, confers a minimum three to ten fold higher risk of T2DM. These findings draw attention to the possible role of leptin in the etiology of T2DM. Furthermore, obesity is also associated with insulin resistance and hyperinsulinemia. It has been reported that Insulin and leptin share a common central signaling pathway [8]. Many studies have demonstrated that taking oral antidiabetic drugs might change the plasma leptin concentration in type 2 diabetes [9].

Metformin hydrochloride, belonging to Biguanides chemically is 1,1-Dimethyl biguanide hydrochloride with a molecular formula of $\mathrm{C}_{4} \mathrm{H}_{12} \mathrm{ClN}_{5}$ is currently the first-line drug treatment for type 2 diabetes [10]. Although considerable efforts have been made since the 1950 s to better understand the action of metformin, its mechanisms of action has not been fully elucidated. The main antidiabetic effect of this drug is to decrease hepatic glucose production [11]. Metformin appears to have several, incompletely understood but complementing each other, modes of action the main mechanisms include anorexiogenesis, reduction of intestinal carbohydrate absorption, inhibition of hepatic gluconeogenesis, as well as increased glucose uptake by peripheral tissues [10].

Metformin-induced inhibition of hepatic gluconeogenesis has been ascribed to several mechanistic cascades. Potential mechanisms are the direct inhibition of gluconeogenic enzymes phosphoenolpyruvate carboxykinase, fructose-1,6-bisphosphatase, and glucose- 6phosphatase [12] and also metformin has been reported to have no effect or modest reduction on plasma leptin level with short-term use, and to reduce plasma leptin with long-term use [13]. Clinically, it has been suggested to reduce food intake in diabetic and non-diabetic patients through specific effects at the level of the hypothalamic centers regulating satiety and feeding [14].

Glibenclamide also known as glyburide, is an oral hypoglycemic of the sulfonylurea group that is frequently prescribed, for the treatment of noninsulin dependent diabetes mellitus [15]. Chemically is 5-chloro-N-[2-4 [[[(cyclohexylamino)carbonyl] amino] sulphonyl]phenyl]ethyl] 2 methoxybenzamide [16]. Insulin secretagogues, including sulfonylureas, correct hyperglycemia by stimulating insulin secretion. Insulin stimulates the secretion of leptin, which explains the elevated level of leptin by sulphonylureas [17]. Hyperleptinemia is associated with obesity and has been used as an index of leptin resistance and bulking of adipose tissue [18].

\section{Patients and Methods}

The study involved 84 volentears divided into four groups. Control group consists of 20 apparently healthy individual. Group1 consists of 23 newly diagnosed type 2 diabetic patients diagnosed at the National Diabetes Center / AL -Mustansiriya University, Group2 consists of 21 patients on metformin therapy and group 3 consists of 20 patients on metformin plus glibenclamide therapies. The four groups were matched regarding age and BMI.

Patients with renal failure, Cushing syndrome or hepatic diseases were excluded from the study after the clinical evaluation. Patients taking oral hypoglycemic agents other than metformin or glibenclamide and those taking drugs that may affect the levels of the G6Pase and leptin had also been excluded. The samples were taken early in the morning between (8.30 and 11.00 A.M) while both patient and healthy subjects were relaxed and fasting for (12-14) hours.

The blood sample was divided into two aliquots; $2 \& 8 \mathrm{ml}$. The first aliquot blood was dispensed in a tube containing Ethylene Diamine Tetraacetic Acid (EDTA), this blood mixed gently and used for HbA1c estimation, While the second aliquot was dispensed in a plain tube and left for around an (2-3min at room temperature) to clot at room temperature $\left(25^{\circ} \mathrm{C}\right)$, and then separated by centrifuge at (3000 rpm) for $(10 \mathrm{~min})$ to collect serum. The serum was divided into two Eppendorff tubes 
and stored in the deep Freeze $\left(-20^{\circ} \mathrm{C}\right)$ until the assay day. G6Pase was measured using ELISA kit (Sandwich) supplied by Cusabio (USA), serum leptin was measured using DRG Leptin (Sandwich) ELISA provided by DRG Instruments $\mathrm{GmbH}$, Germany, HbA1C \% was measured using The CLOVER A1C test system, fasting plasma glucose concentration was estimated by glucose-oxidaseperoxidasecolorimetric method by using a kit supplied by Spinreact (Spain), serum cholesterol, triglycerides and HDL-Cholesterol were measured using Kits supplied by Randox U.K.

\section{Statistical Analysis}

The data was analyzed with SPSS version 17.1 for windows software. All values were expressed as Mean \pm SE and $\mathrm{P}$ value of $<0.05$ was considered to be statistically significant and Paired t-test was used to compare the results of various parameters among the studied groups.

\section{Discussion and Results}

From 64 patients with type 2 diabetes patients and 20 healthy subjects, the result in Table (1) showed that the Mean \pm SE value of G6Pase was $61.99 \pm 5.43$ in diabetic patients and $30.90 \pm 3.02$ in control with $p$ value 0.0023 (significant), the level of FPG in diabetic patient and control was $9.00 \pm 0.36$, $4.67 \pm 0.09$ respectively and $p$ value 0.0001 (significant), while the Mean \pm SE of leptin was $17.10 \pm 1.04$ in diabetic patient and $5.73 \pm 0.63$ in control with $\mathrm{p}$ value 0.0001 (significant) and the level of BMI was $26.52 \pm 0.45$ in diabetic patient and $23.16 \pm 0.64$ in control with $p$ value 0.0003 (significant).

Table (1)

Biochemical parameters for the diabetic and control.

\begin{tabular}{|c|c|c|c|}
\hline \multirow[b]{2}{*}{ Parameters } & \multicolumn{2}{|c|}{ Mean \pm SEM } & \multirow[b]{2}{*}{$P$-value } \\
\hline & $\begin{array}{c}\text { Control } \\
N=20\end{array}$ & $\begin{array}{c}\text { Diabetic } \\
\text { Patients } \\
N=64\end{array}$ & \\
\hline $\mathrm{BMI}(\mathrm{Kg} / \mathrm{m} 2)$ & $23.16 \pm 0.64$ & $26.52 \pm 0.45$ & $0.0003 *$ \\
\hline "G6Pase(U/ml) & $30.90 \pm 3.02$ & $61.99 \pm 5.43$ & $0.0023 *$ \\
\hline FPG(mmole/L) & $4.67 \pm 0.09$ & $9.00 \pm 0.36$ & $0.0001 *$ \\
\hline Leptin(ng/ml) & $5.73 \pm 0.63$ & $17.10 \pm 1.04$ & $0.0001 *$ \\
\hline
\end{tabular}

$*$ P value is significant $<0.01$ level.
The biochemical findings of this study showed that mean G6Pase activity and FPG were found to be elevated in diabetic patients compared with control group. In type 2 diabetes the resistance of liver to insulin leads to uncontrolled gluconeogenesis there is an overexpression of glucose-6-phosphatase, leading to increased endogenous glucose production [6].

Type 2 diabetes is characterized in part by increased endogenous glucose production, much of the increase in endogenous glucose production is related to increased hepatic glucose output. Control of hepatic glucose output occur through regulation of gluconeogenesis or glycogenolysis and the common final pathway of glucose release involves the dephosphorylation of glucose via glucose-6-phosphatase (G6Pase) [19]. So this study found that G6Pase activity is increased leading to an increase in endogenous glucose production in patients with type 2 diabetes and therefore FPG will increase. Also it was found a significant increase of leptin hormone in diabetic patients compared to control he elevated leptin level in T2DM could be contributed to:

Leptin concentration is modulated by weight gain and loss in adult humans. Obesity is strongly associated with development of T2DM. Adipose-derived hormone, leptin has been implicated in the regulation of body weight and energy homeostasis. Circulating leptin concentrations reflect the amount of adipose tissue in the body [20], and as we know the strong relationship between T2DM and obesity so the elevated leptin might be due to increased body mass or may be due to elevated insulin level in T2DM stimulates leptin expression/ release [21]. 
Table (2)

Compare between different groups in study parameters.

\begin{tabular}{|c|c|c|c|c|c|}
\hline \multirow[b]{2}{*}{ Parameters } & \multicolumn{4}{|c|}{ Mean \pm SEM } & \multirow[b]{2}{*}{$P$-value } \\
\hline & $\begin{array}{c}\text { Control } \\
N=20\end{array}$ & $\begin{array}{c}\text { Group1 } \\
\text { Newly } \\
\text { diagnosed } \\
N=23\end{array}$ & $\begin{array}{c}\text { Group } 2 \\
\text { Metformin } \\
N=21\end{array}$ & $\begin{array}{c}\text { Group } 3 \\
\text { Metformin+ } \\
\text { glibenclamide } \\
N=20\end{array}$ & \\
\hline $\begin{array}{l}\text { Age } \\
\text { Years }\end{array}$ & $40.50 \pm 1.83$ & $53.65 \pm 0.93 \mathrm{a}$ & $54.29 \pm 0.75 b$ & $53.70 \pm 0.60 c$ & $0.0001 *$ \\
\hline $\mathrm{BMI}(\mathrm{Kg} / \mathrm{m} 2)$ & $23.16 \pm 0.64$ & $27.15 \pm 0.76 \mathrm{a}$ & $25.98 \pm 0.74 b$ & $26.38 \pm 0.87 \mathrm{c}$ & $0.0025^{*}$ \\
\hline FPG mmole/L & $4.67 \pm 0.09$ & $12.00 \pm 0.49 \mathrm{a}$ & $6.96 \pm 0.28 \mathrm{~b} \mathrm{~d}$ & $7.70 \pm 0.28 \mathrm{c} \mathrm{e}$ & $0.0001 *$ \\
\hline HBA1c\% & $4.35 \pm 0.14$ & $9.39 \pm 0.26 \mathrm{a}$ & $7.40 \pm 0.40 \mathrm{~b} \mathrm{~d}$ & $7.09 \pm 0.23 \mathrm{c} \mathrm{e}$ & 0.0001* \\
\hline $\begin{array}{c}\text { Cholesterol } \\
\text { mmole/L }\end{array}$ & $4.06 \pm 0.20$ & $5.13 \pm 0.24 \mathrm{a}$ & $4.45 \pm 0.32$ & $3.78 \pm 0.29 \mathrm{e}$ & $0.0029 *$ \\
\hline $\begin{array}{c}\text { Triglyceride } \\
\text { mmole/L }\end{array}$ & $1.36 \pm 0.10$ & $2.09 \pm 0.20 \mathrm{a}$ & $1.64 \pm 0.16$ & $1.81 \pm 0.13$ & $0.0111^{*}$ \\
\hline "HDL mmole/L & $1.40 \pm 0.07$ & $1.08 \pm 0.03 \mathrm{a}$ & $1.21 \pm 0.04 \mathrm{~b}$ & $1.11 \pm 0.04 \mathrm{c}$ & "0.0001* \\
\hline LDL mmole/L & $1.80 \pm 0.11$ & $2.98 \pm 0.18 \mathrm{a}$ & $2.57 \pm 0.27 b$ & $1.82 \pm 0.28 \mathrm{e}$ & $0.0003 *$ \\
\hline $\begin{array}{l}\text { G6Pase U/ml } \\
\end{array}$ & $30.90 \pm 3.02$ & $113.95 \pm 5.26 \mathrm{a}$ & $31.35 \pm 2.93 \mathrm{~d}$ & $34.44 \pm 3.34 \mathrm{e}$ & 0.0001* \\
\hline Leptin $\mathrm{ng} / \mathrm{ml}$ & $5.73 \pm 0.63$ & $21.67 \pm 1.22 \mathrm{a}$ & $12.07 \pm 1.48 \mathrm{~b} \mathrm{~d}$ & $\begin{array}{c}17.14 \pm 2.08 \mathrm{c} \\
\mathrm{ef}\end{array}$ & $0.0001 *$ \\
\hline
\end{tabular}

$* P$ value is significant $<0.01$ level.

a) indicate significant difference between control and Group 1.

b) indicate significant difference between control and Group 2.

c) indicate significant difference between control and Group 3.

d) indicate significant difference between Group1 and Group 2.

e) indicate significant difference between Group1 and Group 3.

f) indicate significant difference between Group2 and Group 3.

Effect of anti diabetic drugs on G6Pase, FPG and HbA1c \%

The mean G6Pase activity in group1 (113.95 \pm 5.26$)$ was found to be significant elevated compared with group $2(31.35 \pm 2.93)$ and group $3(34.44 \pm 3.34)$ that treated with anti diabetic drugs as shown in Table (2). There was no significant differences when compared control group with group 2 and group 3. FPG levels in group $1(12.00 \pm 0.49)$ was found to be significant elevated compared with group $2(6.96 \pm 0.28)$ and group $3(7.70 \pm$ 0.28 ) as shown in Table (2). This results shows that G6 Pase activity and FPG were significantly lowered in metformin and metformin plus glibenclamide treated groups compared with newly diagnosed group. Some previous studies showed that metformin therapy was associated with an increase in hepatic glycogen and normalization of glucose-6-phosphatase enzyme activity in diabetic rats [22]. Ripudaman et al (2000) found that metformin treatment in the diabetic human decreased rates of glucose production through a reduction in the rate of gluconeogenesis [23]. The results revealed that using metformin as a mono therapy or combination with glibenclamid may reduce hepatic glucose production by reducing G6Pase activity leading to decrease FPG levels and G6P ase activity levels can be used as an indicator for the choice of treatment in those diabetic patients.

Table (2) shows that the level of HbA1c\% was found lower in groups taking anti diabetic drugs and that agree with Taqua et al (2011) who have demonstrates that anti diabetic drug such as metformin and glibenclamide produced significant decrease in HbA1c levels compared to pre-treatment values [24]. 


\section{Effect of anti diabetic drugs on leptin hormone and BMI.}

The mean leptin concentration in group 1 $(21.67 \pm 1.22)$ was found to be significant elevated compared with group2(12.07 \pm 1.48$)$ and group $3(17.14 \pm 2.08)$ that treated with anti diabetic drugs as shown in Table (2). Many studies have demonstrated that taking oral antidiabetic drugs change the serum leptin concentration in type 2 diabetes [9]. In group3 the mean leptin concentration $(17.14 \pm 2.08)$ was found to be significant elevated compared to group $2(12.07 \pm 1.48)$ this result demonstrate that using metformin monotherapy reduced leptin levels more than metformin combination with glibenclamide and this is similar to the findings in a group of patients studied by other researchers [24]. Glibenclamide correct hyperglycemia by stimulating insulin secretion. Insulin stimulates the secretion of leptin, which explains the elevated level of leptin by sulphonylureas (glibenclamide) [17]. So serum leptin concentration can be used as an indicator for the choice of treatment in those diabetic patients. And because of the strong relationship between T2DM and obesity the elevated leptin in three group diabetic patients might be due to increased body mass index as shown in Table (2).

\section{Effect of anti diabetic drugs on lipid profile.}

The result in Table (2) showes that the Mean \pm SE value of cholesterol was $5.13 \pm 0.24$ in group $1,4.45 \pm 0.32$ in group 2, $3.78 \pm 0.29$ in group3 and $4.06 \pm 0.20$ in control group. Group 1 when compared with group 2 showed non significant differences but there is a significant differences when compared with group 3, so this result revealed that using metformin plus glibenclamide treatment showed a favorable effect on cholesterol than using metformin alone [25]. For triglyceride Mean \pm SE value was $2.09 \pm 0.20$ in group $1,1.64 \pm 0.16$ in group 2 , $1.81 \pm 0.13$ in group 3 and $1.36 \pm 0.10$ in control group. Group 2 and group3 when compared with control group showed non significant differences, this result revealed that use of metformin/ glibenclamide combination or metformin alone in the treatment of T2DM maintained triglyceride levels closer to that of non-diabetic controls [25] .The Mean \pm SE value for HDL-C was $1.08 \pm 0.03$ in group 1 , $1.21 \pm 0.04$ in group 2, $1.11 \pm 0.04$ in group 3 and $1.40 \pm 0.07$ in control group. The result revealed that mean HDL-C was found to be lower and significantly different in three groups diabetic patients when compared with control group. Type 2 diabetes is characterized by low HDL cholesterol (HDL-C) and HDL dysfunction [26]. This result in agreement with Howard et al (1999) who found that insulin resistance may be responsible for low HDL in patients with T2DM [27], where there has been a decrease in HDL production due to alterations in hepatic lipase, which facilitates HDL clearance. Anti diabetic drugs produce a non-significant effect on HDL-C.

In Serum Low Density Lipoprotein LDL-C the Mean \pm SE value was $2.98 \pm 0.18$ in group $1,2.57 \pm 0.27$ in group $2,1.82 \pm 0.28$ in group 3 and $1.80 \pm 0.11$ in control group. Group1 showed non significant difference with group 2 but when compared with group3 showed a significant difference.Group 3 with metformin and glibenclamide treatment shows a favorable effect on LDL-C levels and closer to that of non-diabetic controls group because taking glibenclamide treatment lead to significant reduction in total cholesterol and low-density lipoprotein cholesterol [28].

\section{Conclusions}

Using metformin as a mono therapy or combination with glibenclamide can reduce G6Pase activity, FPG and $\mathrm{HbA1c} \%$ levels in type 2 diabetic patients. Metformin monotherapy reduced leptin levels more than metformin combination with glibenclamide in type 2 diabetic patients so G6 Pase activity and serum leptin cocentration can be used as an indicator for the choice of treatment in those diabetic patients.

Metformin alone produce a non-significant favorable effect on all lipids profile parameters, while metformin plus glibenclamide showed a significant reduction in TC and LDL-C.

\section{Acknowledgment}

Thanks to employeses of the National center of Diabetes in AL-Mustansiria University to cooperate and provide facilities. 


\section{References}

[1] American Diabetes Association, "Diagnosis and Classification of Diabetes Mellitus", Diabetes Care, 37 (1), S81-S90, 2014.

[2] Asnawi A., Anna P., Maximilian D., Johannes S., "The magnitude of association between overweight and obesity and the risk of diabetes: a meta- analysis of prospective cohort studies", Diabetes Research \& Clinical Practice, 89(3), 309319, 2010.

[3] Robert C., "Fine tuning of blood glucose concentrations", Trends biochem. Sci., 10 (2), 70-75, 1985.

[4] Arun K., Bhattacharya S., Nithya S., "Design, Synthesis and Glucose-6Phosphatase Inhibitory Activity of Diaminoguanidine Analogues of 3Guanidinopropionic Acid and Amino Substituted (Pyridin-2-Yl) thiourea Derivatives", J. Pharm. Sci. \& Res., 3(1), 896-902, 2011.

[5] Emile V., Isabelle G., "The glucose-6phosphatase system", Biochem. J., 362(3), 513-532, 2002.

[6] Saima S., "The potential effect of vanadium compounds on glucose-6phosphatase", Bioscience Horizons, 6,1-11, 2013.

[7] Michael A., Olivia M., Christos S., "Leptin in congenital and HIV-associated lipodystrophy", Metabolism clinical and experimental, 64 (1), 47-59, 2015.

[8] Kawaljit K., Sharda S., Gurcharan K., "Relationship between serum leptin and type 2 diabetes mellitus and their association with obesity and menopausal status", Archives of Applied Science Research, 5 (5), 38-44, 2013.

[9] Ciaraldi T., Kong A., Chu N., Kim D., Baxi S., Loviscach M., Plodkowski R., Reitz R., Caulfield M., Mudaliar .S, Henry R., "Regulation of glucose transport and insulin signaling by troglitazone or metformin in adipose tissue of type 2 diabetic subjects", Diabetes, 51(1), 30-36, 2002.

[10] Marc F., Bruno G., Luc B., Michael P., Benoit V., "Metformin: From Mechanisms of Action to Therapies", Cell Metabolism, 20(6), 953-966, 2014.
[11] Benoit V., Marc F., "Revisiting the mechanisms of metformin action in the liver", Annales d'Endocrinologie, 74(2), 123-129, 2013.

[12] Cheng J., Huang C., Liu I., Tzeng T., Chang C., "Novel mechanism for plasma glucose-lowering action of metformin in streptozotocin-induced diabetic rats", Diabetes, 55(3), 819-825, 2006.

[13] Doogue M., Begg E., Moore M., Lunt H., Pemberton C., Zhang M., "Metformin increases plasma ghrelin in Type 2 diabetes", Br. J. Clin. Pharmacol., 68(6), 875-882, 2009.

[14] Grégory A., Virginie M., Marie-Jeanne V., Luc P., François P., "The anorexigenic effects of metformin involve increases in hypothalamic leptin receptor expression", Metabolism Clinical and Experimental, 60(3), 327-334, 2010.

[15] Gamal A., Gamal M., "Assessment of the Physicochemical Properties and In Vitro Dissolution of Glibenclamide Tablets Marketed in Saudi Arabia" Dissolution Technologies, 21(4), 61-66, 2014.

[16] NABIL A., "Derivative Spectrophotometric and HPLC Validated Methods for Simultaneous Determination of Metformin and Glibenclamide in Combined Dosage Form", Orient. J. Chem., 30(4), 1507-1516, 2014.

[17] Hamed E., Zakary M., Ahmed N., Gamal R., "Circulating leptin and insulin in obese patients with and without type 2 diabetes mellitus: Relation to ghrelin and oxidative stress", Diabetes Research and Clinical Practice, 94(3), 434-441, 2011.

[18] Marcelo C., William G., "Does selective leptin resistance cause obesity-related hypertension", Rev Bras Hipertens, 15(4), 189-194, 2008.

[19] John N., Julie S., Harvey S., "Glucose-6Phosphatase Flux In Vitro Is Increased in Type 2 Diabetes", Diabetes, 49(6), 969974, 2000.

[20] Van G., Wauters M., Mertens I., Considine R., De Leeuw I., "Clinical endocrinology of human leptin", Int. J. Obes. Metab. Disorder., 23(1), S29-S36, 1999.

[21] Martin W., Per B., Werner F., Claus T., Piera E., Eberhard H., Wolfgang R., Walter 
T., Hans T., Hans H., "Insulin and cortisol promote leptinproductionin cultured human fat cells", Diabetes, 45(10), 1435-1438, 1996.

[22] Mohamed Z., Noha A., Mansour H., Lobna F. "Pioglitazone Versus Metformin In Two Rat Models Of Glucose Intolerance And Diabetes", Pak. J. Pharm. Sci., 23(3), 305-312, 2010.

[23] Ripudaman S., Martin K., Sylvie D., Didier L., Vincent L., Visvanathan C., Silvio E., William C., Kitt F., Bernard R., Gerald I., "Mechanism by Which Metformin Reduces Glucose Production in Type 2 Diabetes" Diabetes, 49(12), 20632069, 2000.

[24] Taqua A., Ban H., Khalid I., Saad A., "Effects of glibenclamide, metformin or their combination on the correlation between serum leptin levels with glycemic control and insulin levels in type 2 DM", J. Pharm. Biomed. Sci., 1(2), 23- 28, 2011.

[25] Reyadh H., "Effects of Metformin, Glyburide and their Combination on Lipid Profile in NIDDM Patients", Medical Journal of Babylon, 9(4), 936-945, 2012.

[26] Gian P., Elisabetta I., Maria C., Saula V., Angelo A., "Insulin-induced glucose control improves HDL cholesterol levels but not reverse cholesterol transport in type 2 diabetic patients", Atherosclerosis, 235(2), 415-417, 2014.

[27] Howard, B. V., "Insulin resistance and lipid metabolism", American Journal of Cardiology, 84(1A) 28J-31J, 1999.

[28] Kassim S., "Comparative effect of Metformin and Glibenclamide on Lipid profile in type 2 Diabetic Patients", Tikrit Journal of Pharmaceutical Sciences, 7(1), 46-50, 2011.
أجريت هذه الدراسة لتقييم آثار العقاقير المضادة لمرضى

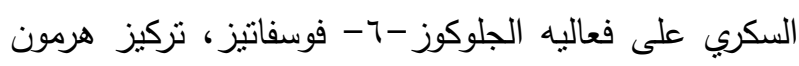

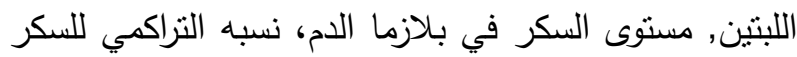
ومستوى الدهون في مرضى السكري من النوع الثاني. وشملت بلت بردي الدراسة § ا مريضا يعانون من داء السكري من النوع الثاني. تم تقسيمهم إلى ثلاث مجاميع اعتمادا على نوع العلاج المستخدم, تشمل المجموعة الأولى ب r مريضا تم تشخيصهم حديثا من دون اخذ أبي نوع من العلاج وتتشمل المجموعة

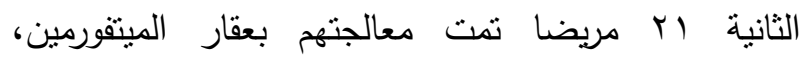
والمجموعة الثالثة تشمل · r مريضا تمت معالجتهم بعقار

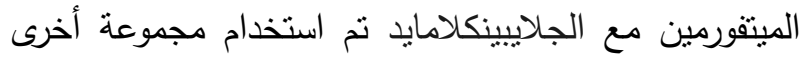

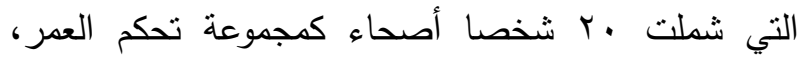

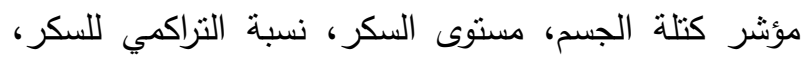
مستوى الدهون، فعاليه الجلوكوز -1- فوسفاتيز وتركيز هرمون الليبتين نم تحديدهم. أظهرت النتائج أن فعاليه الجلوكوز -1- فوسفاتيز كان أقل في المجموعات التي تنتاول العلاج بالمقارنة مع المجموعة التي تم تشخيصها حديثا وأقرب إلى قيم المجموعة الضابطة، وكان تركيز هرمون بانه اللييتين أقل في مجموعة الميتفورمين من مجموعه الميتقورمين

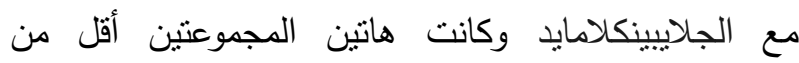
المجموعة التي تم تتخيصها حديثا. مستويات السكر، ونسبه التراكمي للسكر انخفضت في المجموعات الني تتتاول العلاج بالمقارنة مع المجموعة التي تم تشخيصها حديثا. الميتفورمين

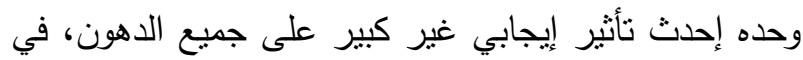

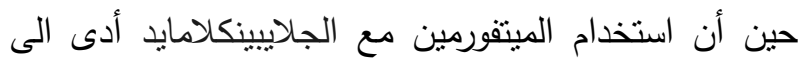
انخفاض كبير في مستوى TC و TDL-C.

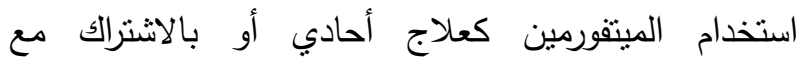

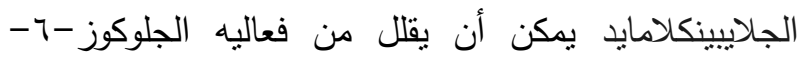

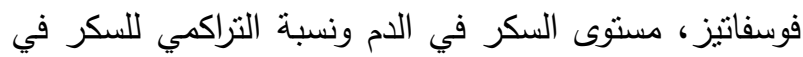
مرضى السكر من النوع الثاني و الميتفورمين وحده يخفض

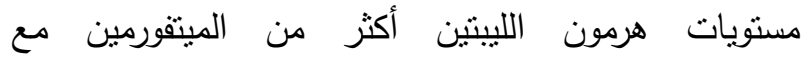
الجالاييينكلامايد في مرضى السكري من النوع الثاني لذلك

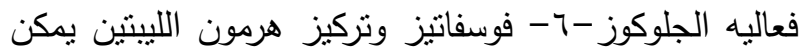

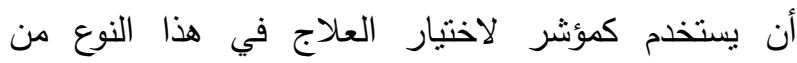

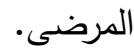

